\title{
MENDESAIN LOGO
}

\author{
Abdul Azis Said \\ Fakultas Seni dan Desain Universitas Negeri Makassar \\ abd.azis.said@unm.ac.id
}

\begin{abstract}
Abstrak
Desain logo yang dirancang dengan baik akan berpengaruh secara signifikan terhadap khalayak sasaran (target audiens) yang dibidiknya, dimana tampilan visual logo dapat langsung menginformasikan bagaimana bisnis tersebut (baik berupa produk ataupun jasa) dapat memuaskan calon konsumen/klien (Cortiss, Gordon, \& Nubie, 2015). Vladimir Gendelman (desainer, founder dan CEO Company Folders, Inc.) menuliskan dalam sebuah artikel bahwa Desain Logo sebuah perusahaan yang paling berhasil tidak hanya menampilkan merek perusahaan itu, namun desain tersebut juga mempresentasikan pesan/informasi dari perusahaan tersebut. Desainer logo dapat disejajarkan seperti halnya seorang ahli juru masak (master chef) yang mampu meramu/mengolah berbagai bahan makanan dalam suatu komposisi tertentu sehingga menghasilkan jenis makanan yang lezat dan menggiurkan (Gendelman, 2015). Mendesain logo selalu diawali dengan mengetahui/memahami eksistensi, visi, dan misi dari 'entitas' yang akan dibuatkan logonya. Selain sebagai acuan untuk mem-visualisasi-kan informasi tentang 'entitas' tersebut, juga sekaligus dapat digunakan dalam memilih dan menentukan jenis logo apa yang cocok untuknya. Tahapan selanjutnya, mengolah dan menata unsur-unsur visual menjadi satu kesatuan komposisi yang harmonis dan estetis, dengan tetap mempertimbangkan faktor-faktor determinan yang terkait dengan eksistensi 'entitas' yang bersangkutan.
\end{abstract}

Kata kunci: desain, logo, perusahaan.

\begin{abstract}
A well-designed logo design will have a significant impact on the target audience, where the visual display of the logo can directly inform how the business (whether it is a product or service) can satisfy potential customers/clients (Cortiss, Gordon, \& Nubie, 2015). Vladimir Gendelman (designer, founder and CEO of Company Folders, Inc.) wrote in an article that the Logo Design of a most successful company not only featured the company's brand, but the design also presented messages/information from the company. Logo designers can be aligned just like a 'master chef' who is able to process various ingredients in a certain composition to produce a delicious and luscious type of food (Gendelman, 2015). Logo design always begins with knowing/understanding the existence, vision, and mission of 'entity' to be made its logo. In addition to being a reference to visualize information about the 'entity', it can also be used in choosing and determining what type of logo suitable for it. The next step, process and organize the visual elements into a unity of a harmonious and aesthetic composition, while considering the determinant factors associated with the existence of 'entity' concerned.
\end{abstract}

Keywords: design, logo, company.

Menciptakan desain logo yang efektif untuk mempresentasikan sebuah perusahaan secara tepat merupakan suatu proses sintesis pengolahan berbagai unsur-unsur visual yang saling berinteraksi satu sama lainnya untuk menghasilkan komposisi visual yang selain estetis dan menarik, juga yang terpenting mampu menyampaikan pesan/informasi tertentu seperti yang diinginkan. Proses pengolahan unsur-unsur visual tersebut dilakukan dengan cara yang sangat rumit dengan memper- timbangkan berbagai faktor yang terkait, sebab logo harus tampil menonjol di tengah 'keramaian visual' yang saling berlomba mempertontonkan diri. Namun meskipun sebuah logo harus terlihat eksis di tengah 'belantara visual', sebaiknya tampilannya tidak terlalu rumit dan tetap sederhana agar relatif mudah diingat, dipahami dan sekaligus dapat menarik perhatian target audiens yang dibidiknya. Tampilan sebuah logo tertentu tidak hanya sekadar gambar cantik dan indah 
yang bisa dilihat oleh konsumen target audiens saat mereka menggunakan produk atau jasa layanan dari si pemilik logo itu. Tapi tampilannya haruslah merupakan 'wajah' keseluruhan identitas dan eksistensi yang diwakilinya, yang selanjutnya dapat menjadi simbol tersendiri bila setiap saat diperkenalkan kepada masyarakat secara konsisten dan terus-menerus. Simbol itu akan menentukan bagaimana kesan/ perasaan (mental image) orang tentang sesuatu yang diwakilinya. Misalnya, jika logo sebuah restoran terkesan dingin dan tidak menimbulkan selera, maka calon konsumen akan mengaitkan gambar tersebut dengan selera makan mereka.

\section{Fungsi dan Jenis Logo}

\section{A. Fungsi Logo}

Berasal dari kata logotype yang berarti sebuah huruf atau sebuah plat yang dicetakkan dan memiliki makna, biasanya dipergunakan sebagai nama surat kabar atau lambang (pada sekitar tahun 1816). Dalam perkembangannya, logo mengalami deformasi bentuk mulai dari bentuk-bentuk logo yang rumit hingga menjadi sebuah bentuk yang sederhana dan mudah diingat. Berbagai pilihan elemen-pun ikut bertambah, mulai dari penggunaan inisial, nama perusahaan, monogram maupun piktogram. Seiring dengan perkembangan dunia periklanan, peran logo menjadi amat penting terutama dalam pembuatan strategi branding sebuah produk. Fungsi identitas inilah yang merupakan tujuan utama dari sebuah logo. Dengan hanya melihat logo seseorang akan ingat, tertarik, lalu membeli. Dari fungsi ini, logo kemudian menjadi ukuran sebuah citra, baik citra sebuah produk, perusahaan, lembaga maupun organisasi. Pada gilirannya logo berfungsi sebagai salahsatu visual identity bagi sebuah korporat.

Kesimpulannya adalah logo berfungsi sebagai 'tanda' atau 'simbol' dari entitas (perusahaan/ organisasi/lembaga tertentu) yang 'mewakili' kehadiran keseluruhan entitas tersebut dalam bentuk visual, dimana logo tersebut akan menyampaikan pesan komukatifnya kepada masyarakat khalayak (target audience) yang dibidiknya. Sebuah logo pada dasarnya merupakan representasi visual dari semua hal yang menjadi tujuan dari sebuah entitas (baik entitas itu berupa perusahaan, organisasi maupun lembaga). Logo tidak berfungsi untuk menjual, dia hanya mewakili identitas dari suatu entitas tertentu, namun logo merupakan titik awal pengenalan identitas dalam rangka menawarkan produk/jasa sebuah perusahaan/ organisasi/lembaga. Jika diibaratkan dengan seseorang, logo itu adalah wajahnya. Kita bisa mengenali seseorang ketika melihat wajahnya, baru kemudian teringat dengan sifatnya, prilakunya dan sebagainya. Begitu juga dengan logo yang mewakili perusahaan, dimana kita mengenali perusahaan dari logonya, baru kemudian mengingat bagaimana pelayanannya, kualitas produknya, dan sebagainya. Idealnya, sebuah logo harus mampu meningkatkan potensi kesan pertama secara signifikan dari konsumen dan atau target audiens yang dibidiknya.

Oleh karena itu, desain logo yang bagus dan dapat dikatakan berhasil apabila logo tersebut: (1) mampu membangun loyalitas antara bisnis/ jasa dengan konsumen/target audiensnya, (2) mampu membangun identitas merek, dan (3) mampu memberikan tampilan visual yang terlihat mapan dan profesional bagi entitas yang diwakilinya. Dalam perkembangannya, saat ini logo berfungsi sebagai acuan sentral dalam strategi branding sebuah produk/ perusahaan.

\section{B. Jenis Logo.}

Secara garis besarnya, jenis logo dapat dikelompokkan menjadi 3 kategori (Said A. A., 2015), yaitu:

a) Logotype atau biasa juga diistilahkan sebagai Word Marks atau Brand Name, merupakan logo yang hanya tersusun dari bentuk huruf atau kata terucapkan, tanpa simbol,

b) Iconic/symbolic, biasa juga diistilahkan sebagai Device Marks atau Brand Mark, merupakan logo yang tampil hanya berupa ikon atau simbol, atau tersusun dari bentuk tak terucapkan, dan

c) Combination mark. Bisa pula logo terdiri atas keduanya, yaitu merupakan kombinasi dari logotype/brand name dan iconicl symbolic.

Sebagai contoh untuk jenis brandname adalah logo Sony yang hanya tersusun dari kata 'sony', sedang logo Shell yang tersusun dari gambar kerang merupakan jenis logo brand 
mark. Adapun paduan/kombinasi keduanya adalah seperti logo rokok Djarum, yang ter- diri dari tulisan Djarum dan gambar jarum.

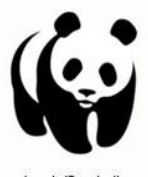

Iconic/Symbolic

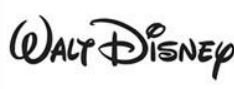

Logotype/Wordmark

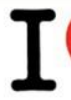

NKRI

Combination
Gambar 1. Contoh kategori jenis logo.

Dengan semakin bertambahnya jumlah produk di pasar dan semakin kompleksnya karakteristik pasar, pada akhirnya memunculkan berbagai jenis logo, yang sebetulnya merupakan paduan dari tiga jenis logo di atas. Menurut John Murphy dan Michael Rowe (1998), jenis logo dapat digolongkan menjadi 7 kategori (Murphy \& Rowe, 1998), yaitu: Name-only Logo, Initial Letter Logo, Name/Symbol Logo, Pictorial Name Logo, Associative Logo, Allusive Logo, dan Abstract Logo.

1) Name-only Logo, biasa pula disebut sebagai 'Logo Huruf' atau logotype atau dikenal pula sebagai alphagram (dalam bahasa Inggeris). Penciptaannya berdasarkan bentuk visual beberapa huruf/angka, yang dirangkai dan digabungkan.

\section{CHANEL Gilletie}

\section{Cartier}

Gambar 2. Contoh logo huruf (Name-only Logo)

2) Initial Letter Logo merupakan logo yang menggunakan huruf awal (inisial) dari nama produk atau perusahaan, yang kemudian menjadikannya inisial itu sebagai elemen utama dari logo tersebut.

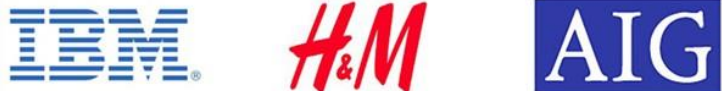

Gambar 3. Contoh Initial Letter Logo.

3) Name/Symbol Logo. Logo jenis ini dapat digolongkan menjadi dua jenis, yaitu:
3.1. Logo Simbol, yaitu logo berupa 'tanda' yang sudah dikenal dan dipahami oleh banyak komunitas bahkan antara bangsa karena sudah menjadi kesepakatan bersama, dimana tanda tersebut dapat menyampaikan 'pesan' yang jelas tanpa membedakan bahasa dan bangsa. Biasanya menggunakan bentuk visual yang sederhana dari suatu obyek untuk mewakili masalah yang berkaitan dengannya.
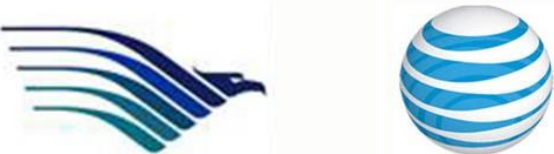

Gambar 4. Contoh Symbol Logo.

3.2. Logo Nama dan Simbol, yaitu logo yang terdiri dari nama perusahaan atau produk dengan gaya tipografis yang berkarakter kuat, tersusun atas bentukbentuk grafis seperti oval, lingkaran atau kotak. Sebagai contoh adalah logo Ford, Kleenex, Hertz dan banyak lagi. Kelebihan jenis logo ini adalah pada bentuknya yang ringkas dan fleksibel karena jenis logo seperti ini mampu berdiri sendiri.
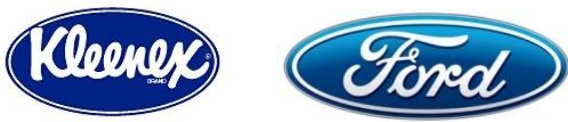

Gambar 5. Contoh logo nama dan simbol.

4) Pictorial Name Logo, adalah logo yang menggunakan nama produk atau organisasi sebagai komponen penting dari gaya logo, yang secara keseluruhan logo ini memiliki gaya yang sangat khusus. Perusahaan yang menggunakan logo jenis ini, biasanya adalah perusahaan yang sudah terkenal, seperti CocaCola, McDonald, Kodak, Nikon, dan sebagainya. Karena kuatnya image perusahaan/produk yang memakai logo ini, maka bila terjadi peniruan logo itu oleh produk atau perusahaan lain maka citra yang dihasilkannya tetap mengarah pada produk atau perusahaan yang ditiru. 


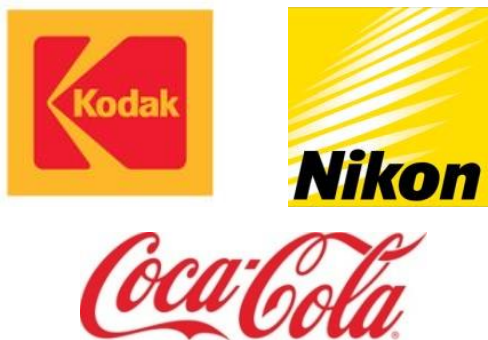

Gambar 6. Contoh Pictorial Name Logo.

5) Associative Logo, yaitu logo yang berdiri bebas yang biasanya tidak memuat nama produk atau perusahaan, tetapi memiliki asosiasi langsung dengan nama, produk atau wilayah aktifitasnya. Sebagai contoh logo perusahaan pembuat pesawat terbang Aerospatiale, logonya terdiri dari kalimat Aerospatiale yang membentuk bola planet yang dengan jelas memperlihatkan jangkauan aktifitasnya yakni penerbangan, logo perusahaan minyak Shell yang menunjukkan gambar 'kerang' sebagai asosiasi dari fosil penghasil minyak. Contoh lainnya, logo perusahaan penerbangan Lufthansa yang menampilkan seekor burung yang terbang sebagai asosiasi dari pesawat terbang yang mampu menjelajahi seluruh dunia (diwakili dengan tampilan lingkaran yang mengelilinginya), dan masih banyak lagi contoh lainnya. Jenis logo seperti ini mempunyai daya tarik kuat dan mudah untuk dipahami.
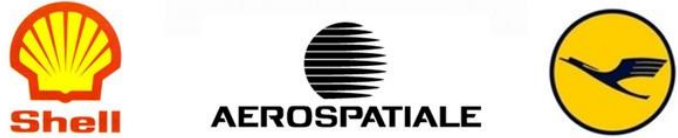

Gambar 7. Contoh Associative Logo.

6) Allusive Logo, adalah logo yang bersifat kiasan, seperti logo Mercedes Benz yang terdiri dari bentuk bintang segitiga yang merupakan representasi dari 'sistem kemudi mobil'; begitu pula bentuk huruf A pada perusahaan penerbangan Alitalia yang dideformasikan dari bentuk ekor pesawat yang berfungsi sebagai penyeimbang. Logo jenis ini memiliki hubungan yang tidak langsung antara nama dengan logonya sehingga logo jenis ini sulit untuk dipahami, dan memerlukan waktu tersendiri agar seseorang bisa memahami apa maksud dari logo yang bersangkutan. Allusive Logo biasa juga disebut sebagai 'Logo Representasi'.
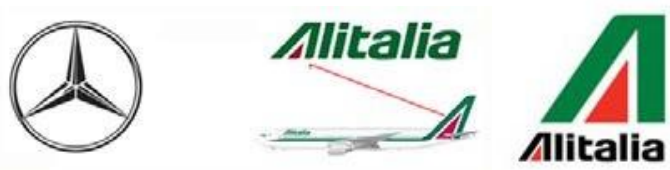

Gambar 8. Contoh Allusive Logo.

7) Abstract Logo, adalah logo yang dapat menimbulkan beraneka kesan, tergantung pada daya tangkap pemahaman konsumen yang melihatnya. Ini terjadi karena bentuk visual logo ini sangat abstrak. Termasuk diantaranya mengambil suatu bentuk struktural yang dikreasikan dengan efek optis yang bervariasi. Sebagai contoh adalah logo Citroen. Logo jenis ini mampu dibuat dengan bermacam variasi dengan tetap mempertahankan keasliannya sehingga banyak perusahaan yang menggunakan logo jenis ini. Bentuk logo abstrak yang ada di Indonesia adalah seperti logo Bakrie Brothers. Kelemahan dari jenis logo ini adalah bentuknya yang abstrak, sehingga sulit dipahami oleh konsumen serta tidak memiliki pengertian yang benar-benar tepat seperti apa yang diinginkan.
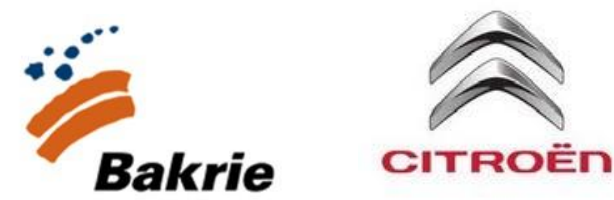

Gambar 9. Contoh Abstract Logo.

\section{Memulai Mendesain Logo}

Hal pertama yang harus diingat bahwa logo didesain bukan untuk dipakai oleh desainer yang menciptakannya, melainkan untuk digunakan oleh klien. Sehingga untuk pembuatan logo yang ideal diperlukan data mengenai klien secara konprehensif, bukan hanya dengan penelitian menggunakan daftar pertanyaan, tetapi juga pengamatan suasana, aspirasi dari setiap orang yang nantinya akan menggunakan logo itu sebagai "pakaiannya" yang selanjutnya akan menandainya. Oleh karena itu, sebelum memulai mendesain $\log o$ dan membuat sketsa ide, langkah awal yang harus dilakukan adalah mendeskripsikan dan mengartikulasikan pesan/informasi yang ingin 
disampaikan oleh logo yang akan dibuat. Sebagai petunjuk awal, mulailah mencoba menuliskan satu kalimat pernyataan misi yang mampu menggambarkan fokus (berupa keunggulan yang akan ditonjolkan) kegiatan, lokasi, produk, jasa/layanan atau hal-hal lainnya dari suatu perusahaan/organisasi/ lembaga yang akan dibuatkan logonya. Jadikanlah sebagai 'pondasi' dan tetap berpegang teguh pada kalimat pernyataan itu dalam setiap langkah proses pembuatan logo. Contoh pernyataan: perusahaan percetakan Rajawali Prima dapat melayani pencetakan dokumen secara cepat dengan kualitas prima. Pernyataan inilah yang harus dijadikan sebagai acuan dalam proses visualisasi logo yang akan dibuat, dimana nantinya desain logonya harus mampu mengilustrasikan tentang 'Rajawali', 'mencetak cepat', dan atau 'kualitas prima'.

Selain daripada pesan/informasi yang akan dikomunikasikan melalui desain logo yang akan dibuat, tentu saja masih ada beberapa faktor lainnya yang harus dipertimabngkan untuk memulai membuat sebuah logo. Berikut adalah beberapa sterategi dan pertimbangan utama yang akan membantu dalam proses membuat sebuah logo yang sesuai dengan keinginan dan marwah suatu perusahaan tertentu.

1) Cermati dan bandingkan dengan kompetitor.

Perhatikan dan bandingkanlah beberapa logo perusahaan lain yang sejenis yang menjadi kompetitor/pesaing. Apakah kompetitor menggunakan gambar yang solid, konservatif, atau kombinasi grafis dan jenis huruf yang mencolok? Kemudian pertimbangkanlah bagaimana cara membedakan logo yang akan dibuat dari para kompetitor tersebut. Hal ini selain dapat dijadikan acuan awal untuk menentukan jenis logo yang akan dibuat juga dapat menjadi alternatif dalam rangka mencari inspirasi lain agar nantinya bisa menghasilkan gambar/grafis yang unik sehingga membuat perbedaan atau differensiasi dengan kompetitor.

2) Fokus pada pernyataan pesan/informasi.

Tentukan apa yang ingin dikomunikasikan tentang perusahaan. Buatlah sebuah kalimat pernyataan yang mampu menggambarkan fokus keunggulan/kelebihan yang akan ditonjolkan dari perusahaan itu. Fokus pernyataan tersebut bisa berupa lokasi, kegiatan, produk, jasa/layanan atau hal-hal lainnya dari perusahaan. Sekali lagi, bandingkan fokus pernyataan yang tergambarkan pada logo kompetitor, apakah itu terdapat perbedaan yang menyolok atau biasa-biasa saja? Apa yang membuatnya berbeda dan unik dalam kaitannya dengan kompetitor?

3) Cermati karakteristik khalayak sasaran (target audiens).

Mencermati karakteristik target audiens dapat ditelususri/dianalisa dengan melakukan segmentasi pasar terhadap konsumen yang dibidik, dengan melihat secara deskriptif terhadap karakteristik: geografis, demografis, psiko-grafis, dan behavioral/prilaku (Kotler \& Keller, 2009).

Geografis: negara, wilayah, atau daerah tertentu.

Demografi: usia, jenis kelamin, pekerjaan, dan sebagainya.

Psikografis: gaya hidup, nilai, kepentingan, dan sebagainya.

Behavioral (prilaku): orang/konsumen menggunakan produk tertentu, dengan alasan: gengsi/simbolik, loyalitas merek, manfaat esensial dari dari produk, dan sebagainya.

Memahami karakter target audiens (konsumen) yang akan dibidik merupakan tindakan bijaksana, karena dapat digunakan sebagai landasan mendesain logo. Sebab, gaya dan bentuk tampilan visual desain logo harus menyesuaikan dengan karakteristik/minat/gaya target audiens agar dapat menarik perhatian mereka, yang selanjut mempengaruhi keinginan membeli/memakai produk yang ditawarkan oleh perusahaan. Umpama, karakteristerik target audiens secara demografis: anakanak, maka tentu saja tampilan visual logo berkarakter sesuai dengan minat anakanak yang informal dan fleksibl; berbeda dengan orang dewasa yang pada umumnya berkarakter formal dan tegas.

4) Buatlah tampilan logo tampak jelas dan fungsional aplikatif.

Logo yang bagus harus terukur, mudah di-reproduksi, mudah diingat dan 
khas/unik. Logo harus dapat diterapkan dengan baik di berbagai stationery, merchandise, produk dan atau berbagai artefak visual yang berkaitan dengan perusahaan (seperti kartu nama, struk nota, amplop, baju kaos, gelas, kemasan, dan sebagainya). Perlu diperhatikan bahwa penggunaan 'ikon/simbol' lebih baik daripada foto, karena foto mungkin tidak tampak bagus jika diperbesar atau dikurangi ukurannya secara signifikan. Hal lainnya, pastikan bahwa logo yang dibuat bisa direproduksi dalam warna hitam dan putih sehingga bisa difaks, difotokopi atau digunakan dalam iklan hitam-putih seefektif bila logo itu berwarna.

5) Nama perusahaan akan mempengaruhi desain logonya.

Nama perusahaan/lembaga sangat berperan penting dalam proses mendesain logo. Pada umumnya perusahaan menginginkan kepopuleran namanya, sehingga desainer dituntut untuk menampilkan nama perusahaan pada logonya, baik sekedar berupa initial ataupun nama lengkap perusahaan. Di sini dibutuhkan kejelian dan keterampilan dalam memilih dan mengolah font yang akan digunakan. Sebaiknya menggunakan jenis huruf hasil olahan sendiri dan tidak meniru font yang bersifat template yang sudah ada, untuk memunculkan keunikan dan perbedaan dengan yang lainnya. Bahkan dapat juga dikombinasikan dengan tanda/ikon/simbol tertentu secara kreatif untuk mengilustrasikan eksistensi perusahaan, seperti umpamanya ikon/simbol 'petir' yang akan memberi kesan ilustratif: kecepatan.

6) Tampilkan keuntungan utama bagi konsumen.

Manfaatkan desain logo untuk menggambarkan keuntungan utama bagi konsumen. Logo yang baik membuat pernyataan langsung dengan gambar atau ilustrasi, bukan kata-kata ataupun kalimat panjang. Misalnya logo "Percetakan Rajawali Prima", mungkin perlu menyampaikan manfaat bisnis dari "layanan percetakan yang sangat cepat dan terjamin kualitasnya", maka gambar ilustrasi yang mungkin dapat ditampilkan adalah burung garuda yang sedang terbang dengan kecepatan tinggi yang dapat diwakili dengan menampilkan 'ilustrasi grafis' yang memberi kesan kecepatan tinggi (seperti garis-garis sejajar yang berujung runcing atau simbol visual yang bisa dimanipulasi untuk memberi kesan kecepatan dan kepastian).

7) Hindari penggunaan 'clip art'.

Meskipun menggoda karena sudah tersedia dan lebih mudah membuatnya, dimana clip art dapat langsung dicopypaste. Namun tidak orisinal dan mungkin sudah digunakan secara umum dimanamana, tidak hanya sebagai logo. Sehingga menampilkan kesan 'murahan' tentang perusahaan, dan yang terpenting tidak tampil unik dan tidak memiliki differensiasi yang signifikan dengan perusahaan lainnya.

8) Hindari tampilan trendi.

Kembangkan ide kreatif yang orisinal dari berbagai sumber inspirasi, dengan demikian logo yang dibuat akan memungkinkan bertahan relatif lama dibandingkan mengikuti trend yang tampil bagus hanya sesaat saja. Ingatlah, trend dalam masyarakat selalu memiliki masa yang tidak lama sehingga logo yang dibuat berdasarkan trend yang sedang berkembang akan beresiko 'berumur pendek'. Sebagai alternatif, pilihlah logo yang diperkirakan akan mampu bertahan hingga 10 sampai 20 tahun, atau mungkin lebih lama lagi.

Perusahaan yang ingin mendesain ulang logonya (redesign logo), beresiko membingungkan pelanggannya, bahkan bisa lebih buruk lagi, bisa saja para pelanggannya merasa 'asing' sendiri. Salahsatu pilihannya adalah membuat perubahan logo secara bertahap, tidak melakukan perubahan mendadak dan total. Sebagai contoh, Quaker Oats membutuhkan waktu bertahap selama 10 tahun dalam rangka memodifikasi logonya, hal ini dilakukan untuk menghindari keterasingan, keresahan, dan kepercayaan pelanggan yang telah lama mengenal identitasnya. Bila melakukan redesain logo, perlu diperhatikan menghindari rencana membuat banyak perubahan terhadap logo terdahulu. 


\section{Makna Logo}

Kriteria terpenting dalam tampilan logo adalah harus mampu menyampaikan pesan/informasi yang dapat dengan relatif mudah dipahami atau dimaknai oleh target audiens (khalayak sasaran) yang dibidiknya. Artinya kriteria 'sesuai dan bermakna' (relevant and meaningful) harus terakomodasi dalam sebuah desain logo. Oleh karena itu, sekali lagi, dalam proses pembuatan logo harus selalu dan tetap fokus pada pernyataan pesan/informasi yang akan disampaikan kepada khalayak sasaran, agar tampilan grafis desain logo mampu dengan mudah dicerna dan dipahami oleh khalayak. Dalam hal ini, biasanya desainer memanfaatkan tanda, ikon, atau simbol-simbol yang telah akrab dikenal oleh masyarakat, seperti umpamanya tanda panah yang menunjukkan arah, jempol ke atas bermakna bagus, tapak kaki berderet yang dapat diartikan sedang berjalan, dan sebagainya.

Di bawah ini ditampilkan beberapa contoh logo perusahaan yang telah dikenal cukup luas di masyarakat, yang dapat dijadikan sebagai bahan banding dalam proses pembuatan logo.

a) Carrefour. Perusahan ini didirikan dan berpusat di Perancis. Dalam bahasa Perancis, nama Carrefour berarti 'persimpangan jalan'. Pada tampilan desain logonya, memberi makna atas pernyataan pesan/informasi tentang lokasi keberadaan perusahaan tersebut yang mudah ditemukan. Hal ini dipresentasikan secara cermat, dengan memanfaatkan komposisi bentuk tampilan huruf $\mathrm{C}$ (sebagai initial huruf dari nama perusahaannya) yang terbentuk di tengahtengah antara bentuk dua anak panah yang saling bertolak belakang. Dua anak panah yang saling bertolak belakang tersebut mempresentasikan persimpangan jalan pada dua arah jalan yang berlawanan. Karena kantor/toko pertamanya terletak pada salahsatu persimpangan jalan. Sehingga 'pesan/informasi' visual logo ini memudahkan orang untuk mengingat lokasi perusahaan/toko itu. Penerapan warna biru dan merah (dua warna yang saling berkomplemen) bermakna untuk mempertegas dua arah jalan yang saling berlawanan itu. b) Gillette. Pada logo 'Gillette', terdapat pesan yang tersembunyi yang sebenarnya agak sulit ditemukan, tapi bila diperhatikan dengan seksama dan teliti maka kita akan melihat sebuah 'tanda' yang mempelihatkan ketepatan/ketajaman pisau-silet ini memotong huruf ' $G$ ' dan 'I'. Tanda tersebut merupakan simbol yang bermakna untuk menunjukkan 'ketajaman dan ketelitian' pisau-Gillette. Pesan/informasinya yang difokuskan adalah pada keunggulan produk pisausilet tersebut, yaitu konsumen akan mendapatkan manfaat bila menggunakan pisau Gillette ini, karena memiliki ketepatan/ketajaman memotong.

c) Baskin Robbins yang membuat ice cream dan menciptakan 31 jenis ice cream dimana setiap jenisnya memiliki perbedaan rasa masing-masing. Desain logonya dengan cerdas meng-elaborasi initial huruf namanya yaitu dengan menggabung antara huruf ' $B$ ' dan ' $R$ ' ke dalam sebuah komposisi sehingga membentuk angka 31 diantara kedua huruf tersebut. Fokus pesan yang ingin disampaikan kepada masyarakat adalah tentang jumlah dan rasa ice cream yang diproduksi oleh Baskin Robbins.

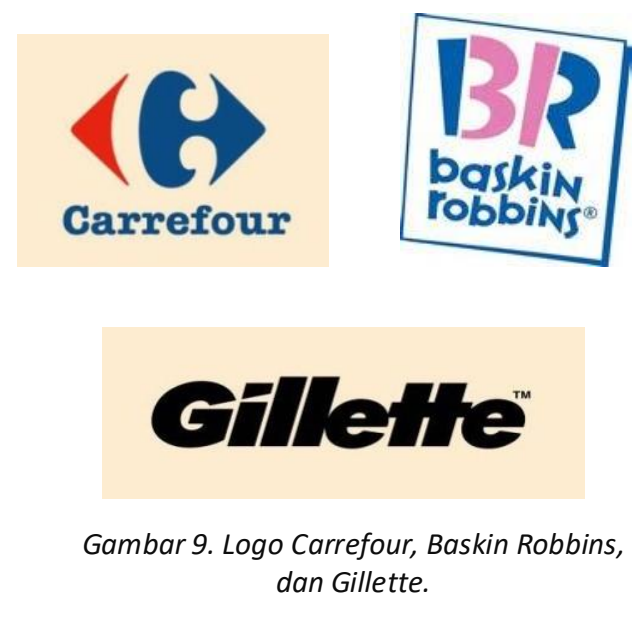

\section{Dimensi dan Proporsi Logo}

Banyak desainer logo seringkali mengabaikan hal dimensi ini, padahal dimensi/ukuran merupakan faktor yang integratif dengan permasalahan desain. Karena setiap benda di dunia ini memiliki ukuran, benda apapun juga, baik dalam wujud dwimatra (dua dimensi) maupun trimatra (tiga dimensi). Ukuran itu 
nisbi (relatif) jika kita berbicara tentang besar dan kecil, tetapi dapat juga diukur dengan pasti. Bila kita melihat sebuah benda, biasanya disengaja atau tidak disengaja, kita membandingkan besar-kecilnya benda itu terhadap benda lain atau ukuran antar unsurunsur yang membentuknya. Namun pada umumnya, dalam membandingkan ukuran sebuah benda, tanpa disadari, kita cenderung membandingkannya dengan ukuran tubuh kita atau benda yang berada disekitarnya. Istilah yang digunakan untuk menuliskan perbandingan ukuran sebuah obyek adalah 'skala', berasal dari kata scale, yang berarti perbandingan ukuran. Penerapan ukuran dalam penggambaran berbagai desain pada bidang papar kertas gambar biasanya mempergunakan skala perbandingan, yaitu ukuran perbandingan nisbi yang digunakan untuk menyatakan besaran desain gambar dalam ukuran 'wujud gambar' dengan ukuran 'wujud benda sebenarnya' (Said A. A., 2006).

Proporsi termasuk prinsip dasar tata rupa untuk memperoleh keserasian tampilan rupa yang estetis. Keserasian rupa dapat tercapai dalam sebuah karya diperlukan perbandingan yang tepat. Pada dasarnya proporsi adalah perbandingan matematis dalam sebuah bidang. Proporsi Agung (Golden Mean atau biasa juga disebut Golden Ratio) adalah proporsi yang paling populer dan dipakai hingga saat ini dalam karya seni rupa hingga karya arsitektur. Proporsi ini menggunakan deret bilangan Fibonacci (Fibonacci Spiral) yang mempunyai perbandingan 1:1,618 atau sering juga dipakai 8:13. Konon proporsi ini adalah perbandingan yang ditemukan di benda-benda alam, khususnya terlihat jelas pada struktur cangkang kulit kerang, juga termasuk struktur ukuran tubuh manusia, sehingga dianggap proporsi yang given atau telah disediakan oleh alam hasil ciptaan Tuhan Yang Maha Kuasa. Dalam kehidupan sehari-hari terutama dalam bidang desain, proporsi ini dapat kita lihat dalam perbandingan ukuran kertas dan layout halaman.

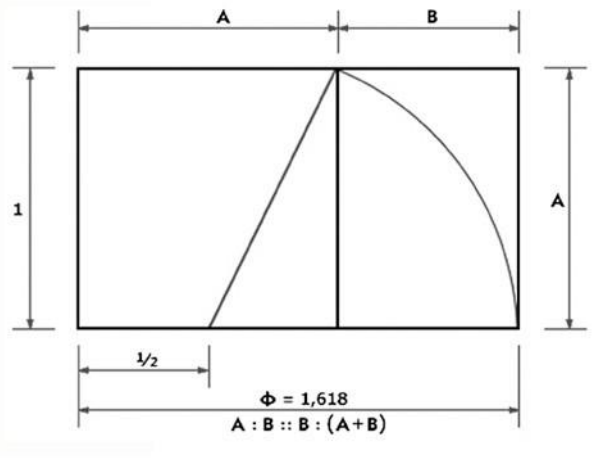

The Golden Mean

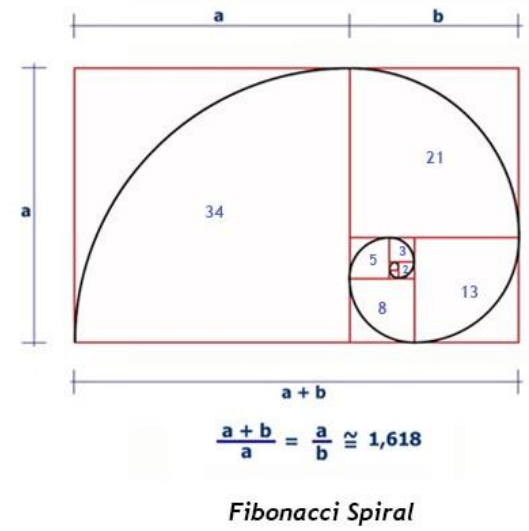

Gambar 10. Rumus Golden Mean dan Fibonacci Spiral.

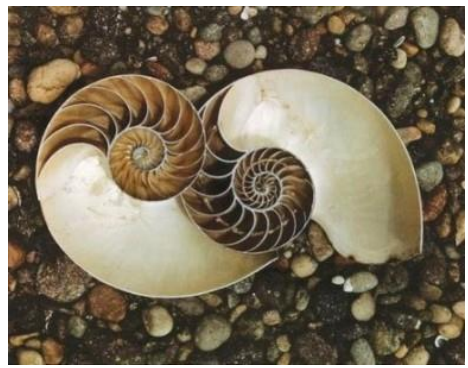

Gambar 11. Struktur cangkang kulit kerang.

Banyak perusahaan telah menyadari manfaat pentingnya proporsi pada desain logonya, karena dengan menerapkan proporsi logo secara betul akan menghasilkan tampilan visual yang lebih estetis, selain itu memudahkan penerapan logo dalam berbagai ukuran media yang digunakan dimana hasilnya akan terlihat sama atau identik meskipun dengan ukuran yang berbeda. Beberapa desain logo yang memanfaatkan prinsip Golden Ratio, antara lain Fish $O$ Fish, Twitter, Apple, dan sebagainya. Salahsatu perusahaan yang berhasil menerapkan prinsip 'golden ratio' pada desain logonya adalah Fish O Fish, dimana bentuk ikan yang dijadikan sebagai ide awal, yaitu dengan menggunakan 3 buah 
lingkaran yang memiliki ukuran perbandingan sama dengan golden ratio.

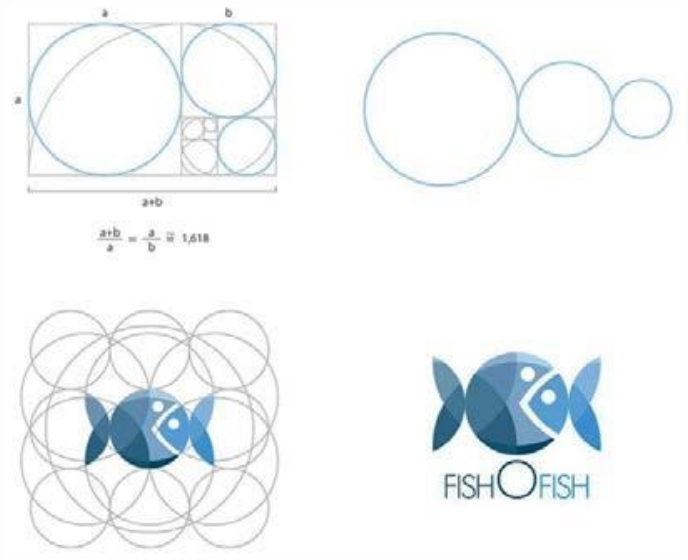

Gambar 12. Proses desain logo Fish O Fish yang menerapkan rumus Golden Ratio.

Desain logo perusahaan Apple terinspirasi dari bentuk buah apel yang kemudian dalam pembuatannya menerapkan golden ratio, demikian juga halnya dengan logo Twitter yang telah dikenal luas.

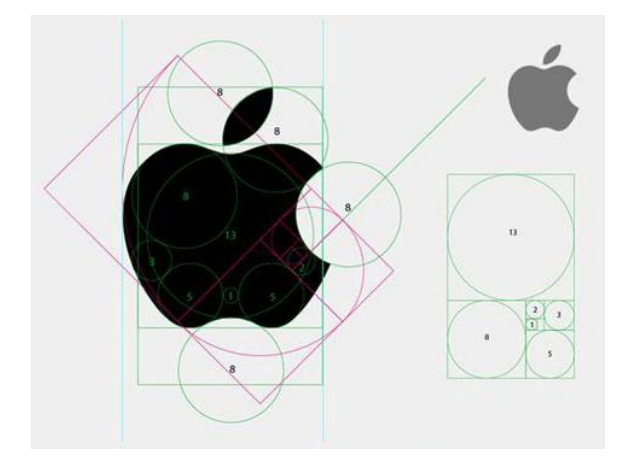

Gambar 13. Logo Apple yang memanfaatkan rumus Golden Ratio.

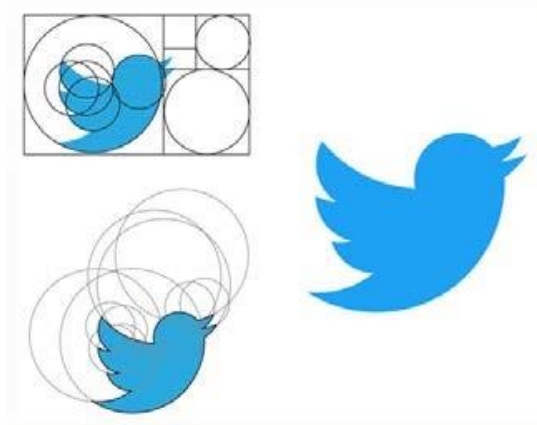

Gambar 14. Desain logo Twitter.

\section{Warna Logo}

Faktor penting yang perlu dipertimbangkan ketika akan mengeksplorasi pilihan warna pada sebuah logo adalah biaya dan aplikasinya pada produk. Logo yang menerapkan lima macam warna memang mungkin terlihat cantik dan menarik, namun begitu tiba waktunya untuk memproduksinya umpamanya pada alat tulis, maka harganya atau biayanya tidak akan menarik karena relatif mahal. Demikian halnya bila logo tersebut tidak bisa diterapkan pada media yang hanya memungkinkan satu atau dua warna, tentunya akan mengalami kesulitan/kendala untuk menerapkannya. Oleh karena itu dalam penciptaan sebuah logo sebaiknya hanya memanfaatkan tidak melebihi tiga warna saja, bahkan untuk lebih sederhana lagi sebaiknya hanya menggunakan satu atau dua macam warna saja, kecuali jika klien yang menginginkan dan memutuskan bahwa hal itu memang mutlak diperlukan. Meskipun demikian, sebagai seorang desainer sebaiknya melakukan advokasi dengan menjelaskan bahwa bila menggunakan banyak warna akan berakibat pada biaya tinggi.

Sebelum menggunakan warna dalam proses menciptaan sebuah logo, selalu harus diingat dan diperhatikan logo tersebut dapat diterapkan dan ditampilkan di berbagai media seperti: signage/papan nama, periklanan, alat tulis, kendaraan pengantar, kemasan, dan lain sebagainya. Ingatlah selalu bahwa beberapa media-aplikasi memiliki keterbatasan dalam proses produksi dalam kaitannya untuk menerapkan logo. Lihat dan pelajari kembali pengetahuan tentang warna, dimana bila menggunakan lebih dari satu warna maka sebaiknya menerapkan warna-warna kontras (Said A. A., 2006); dan hindari menggunakan warna gradasi ataupun transparan. Perlu pula dicoba-terapkankan dimana logo dibuat dalam versi satu warna, lalu perhatikan apakah sebagus tampilan bila menerapkan dua dan atau tiga warna.

\section{Hak Cipta}

Setelah menghasilkan logo yang mewujudkan sekilas tentang misi perusahaan, maka hal lain yang harus dan penting dilakukan adalah memastikan karya desain tersebut mendapat perlindungan terhadap pembajakan atau plagiat dari pihak lain. Oleh karena itu, sebelum menggunakan dan memperkenalkan ke masyarakat umum, sebaiknya mengajukan permohonan perlindungan Hak Cipta dan merek dagang (sebagai bagian dari Hak Kekayaan Intelektual atau HKI) ke Kemen- 
terian Hukum dan Hak Azasi Manusia RI, untuk melindunginya dari penggunaan oleh perusahaan/organisasi/lembaga lain. Untuk lebih memahami tentang Hak Kekayaan Intelektual atau HKI ini, sebaiknya menyimak tulisan/buku "Pengetahuan Hak Kekayaan Intelektual" (Jayadi \& Cahyadi, 2015); lihat juga pada Start Your Own Business (Cortiss, Gordon, \& Nubie, 2015).

Kemudian, setelah dilindungi, barulah desain logo tersebut diaplikasikan di berbagai media yang digunakan oleh perusahaan, seperti umpamanya: signage/papan nama, periklanan, alat tulis, kendaraan pengantar, kemasan, kartu nama, kop surat, brosur, iklan, situs web, dan tempat lain yang menyebutkan nama perusahaan. Dengan demikian akan membantu membangun citra perusahaan dan meningkatkan visibilitas perusahaan, yang selanjutnya mengarah pada peningkatan kegiatan bisnis.

\section{Bibliography}

Cortiss, D., Gordon, K. T., \& Nubie, S. (2015). Start Your Own Business.

http//enterpreneur.com/article .

Gendelman, V. (2015). Qualities Best Buiness Logos Infographics.

https://businesscollective.com/ .

Jayadi, K., \& Cahyadi, D. (2015). Pengetahuan Hak Kekayaan Intelektual. Makassar: Badan Penerbit UNM Makassar.

Kotler, P., \& Keller, K. L. (2009). Manajemen Pemasaran. Jakarta: Airlangga.

Murphy, J., \& Rowe, M. (1998). How to Design Trademarks and Logos. Ohio: North Light Book.

Said, A. A. (2006). Dasar Desain Dwimatra. Makassar: Badan Penerbit UNM Makassar.

Said, A. A. (2015). Desain Logo. Makassar: Fakultas Seni dan Desain UNM Makassar. 